\title{
Comparative Analyses of Levels of Some Trace Metals in Boreholes and Hand-Dug Wells Water Sources Within and Around Lafia Metropolis
}

\author{
S.J. Anzene ${ }^{1}$, S.P. Malu ${ }^{2}$ and Ahile U.J ${ }^{3}$ \\ ${ }^{I}$ Directorate of Advancement and Linkages Nasarawa State Polytechnic, Lafia, Nigeria. \\ ${ }^{2}$ Department of Chemical Sciences Federal University, Wukari, Taraba State, Nigeria. \\ ${ }^{3}$ Department of Chemistry, Benue State University, Makurdi, Nigeria.
}

\begin{abstract}
In this study, the levels of some trace metals ( $A s, C o, C r, C d, P b, A l, N i$ and $M n)$ were determined in boreholes and hand-dug well water sources in Lafia town and its environs using Atomic Absorption Spectrophotometry (AAS). Sampling, preservation of the water samples, pre-concentration and analyses of the trace metals were carried out as prescribed by APHA, AWWA, and WEF Standard Methods for the Examination of Water and Waste Water. In the wet season(WS), the highest mean concentrations $(\mathrm{mg} / \mathrm{L})$ of trace metals from boreholes $(B H)$ was $\mathrm{Mn}(0.7787+0.2389)$ in Lafia West while the least was Pb $(0.0049+0.0001)$ in Lafia South. Similarly for hand-dug wells $(\overline{H D} W)$ in wet season, the highest was Mn $(0.6227 \pm 0.0 \overline{2} 60)$ in Lafia West while the least was As(0.0106 \pm 0.0001$)$ in Lafia East. In dry season(DS), the highest mean concentration of trace metals from BH was Mn(0.3815 \pm 0.0907$)$ in Lafia West while the least was $\mathrm{Cr}(0.0042 \pm 0.0001)$ in Lafia South. Similarly for HDW in dry season, the highest was Mn(0.3588 \pm 0.0762$)$ in Lafia West while the least was $\mathrm{Ni}(0.0065 \pm 0.0001)$ in Lafia Central. However $\mathrm{Cd}$ and $\mathrm{Al}$ were not detected within the two seasons. In all, the analyses revealed the presence of $40 \% \mathrm{As}, 40 \% \mathrm{Co}, 37.5 \% \mathrm{Cr}, 25 \% \mathrm{~Pb}, 25 \% \mathrm{Ni}$ and $97.5 \% \mathrm{Mn}$ from the total ground water samples. Their mean concentrations were compared with standards of a number of regulatory bodies such as World Health Organization (WHO), National Agency for Food Drug and Control (NAFDAC), National Standard for Drinking Water Quality (NSDWQ for Borehole). In comparison, the results showed higher levels of these metals than the maximum tolerable limits, particularly those of As $(0.2710 \pm 0.0001-$ $0.0106 \pm 0.0001)$, Co $(0.2406 \pm 0.2114-0.0281 \pm 0.0001), \operatorname{Cr}(0.5049 \pm 0.5871-0.0272 \pm 0.0001)$ for all the water samples throughout the seasons. However those of $\mathrm{Pb}(0.0423 \pm 0.0537-0.0049 \pm 0.0001), \mathrm{Ni}(0.3729 \pm 0.0001-$ $0.0841 \pm 0.0001), \mathrm{Mn}(0.7787 \pm 0.2329-0.1049 \pm 0.0322)$ were within tolerable limits in most cases. The results indicate that these ground water sources were polluted more prominently in wet season; $B H$ $(W S)>H D W(W S)>B H(D S)>H D W(D S)$ in all locations, with specific reference to $A s, P b$, because of their high toxicities and therefore not safe for drinking.
\end{abstract}

\section{Introduction}

In the development of communities, water plays a vital role; hence a reliable source of water is essential for the existence of both humans and animals. Water supply is mostly derived from precipitation and is often said to be contaminated if it is not suitable for the intended purpose $[1,2]$.

Therefore the presence of heavy metals in water sources has received considerable and special attention for which permissible or recommended limits have been set for water for both domestic and industrial application [3-6].

Assessment of heavy metals is the determination of metal constituents of sample where these constituents make up only a small part of sample generally below or about one hundred parts per million (ppm). The important role of very small amounts of elements in physical, chemical and biological systems has emerged with advances in methods of analysis with increasing sensitivity[7]. The damaging effects of contamination with heavy metals in our environment have become more serious or obvious especially in water [8]. Virtually all metals can produce toxicity when ingested in sufficient quantities but they are several others which are important either because they are pervasive or produce toxicity at low concentration; $\mathrm{Pb}, \mathrm{Hg}, \mathrm{As}$ and $\mathrm{Cd}$ are prime examples and serve no biological function. On the other hand, metals like $\mathrm{Cr}, \mathrm{Cu}, \mathrm{Fe}, \mathrm{Mn}, \mathrm{Se}, \mathrm{Mo}$ and $\mathrm{Zn}$ though occur in small amounts are essential in our diet because they are key components or constituents of important biological molecules such as enzymes, $\mathrm{Hb}$, Metallic activators, pigments, determinants of osmotic pressure and other biological compounds that are essential to life.

The concern of people globally, on water pollution, as it affects human health is the direct disposal of waste materials into the land surface thereby causing ground water pollution. The waste products or materials occur as individual mounds or it may spread out over the land. If the waste materials contain soluble materials, they will infiltrate thereby causing the ground water to be polluted [9]. 
In many Nigerian urban centres, the per capita consumption of water which is about $80 \mathrm{~L} / \mathrm{d}$ appears quite low as compared to $115 \mathrm{~L} / \mathrm{d}$ which is considered more appropriate for urban dwellers in a country like Nigeria and even then only $17.2 \%$ of Nigerians have access to clean water [10]. In view of the shortfall in the supply of public treated water in urban centres of the nation, most inhabitants have to look for alternative sources of water especially ground water in form of boreholes and hand-dug wells which are untreated. The population of Lafia being the state capital of NasarawaState has increased tremendously since its creation in 1996, with accompanying increase in human activities. One of the economic activities in the state is mineral exploration because of the huge mineral occurrence which the state is fondly tagged "Home of Solid Minerals" and these no doubt affect the soil and water in which life critically depends. Prominent among the minerals in this area are coal, barytes, salts, limestones, cassitterite, columbite, clays, glasssand, lead-zinc and hydrocarbon potential[11].

\subsection{Materials}

\section{Materials And Methods}
i)
(ii) Methyl Isobutyl Ketone (M.I.B.K.)
(iii) Ammonium PyrolidineDithiocarbamate (APDC) from which 5\% was prepared.
(iv) Concentrated nitric acid of M \& B Analytical Reagent
(v) Trace metals standards
(vi) Atomic Absorption Spectrophotometer(AAS)- SOLAAR 32 AA
(vii) $\quad \mathrm{pH}$ Meter- $\mathrm{pHep}, \mathrm{pH}$ Tester CE of Hanner Instruments Woonsocket: R102895
(viii) Buffer solution ( $\mathrm{pH} 7.0)$.

\subsection{Geology of the study area}

The study area is Lafia metropolis (Figure 1) with about fifty neighbourhoods [56]. Lafia is the capital of NasarawaState which is located in the middle belt region of Nigeria. The state lies between longitudes $7^{\circ}$ and $9^{\circ} 37^{\prime}$ E of the Greenwich Meridian and has an altitude of $181.5 \mathrm{~m}$ above sea level [12].

Lafia is located within the geological Afo Younger Granites complex within the Middle Benue Trough. Afo younger granite complex is the youngest granite complex in Nigeria. The Younger Granites are distinctive series of alkali feldspar granites hosting minerals like cassitterite, columbites as major minerals. Lafia which is the last segment of the Middle Benue Trough is underlined by basement complex rocks and has appreciable layer of sedimentation notable for water retention [13].

\subsection{Sample collection and preservation}

The samples for this investigation were collected randomly from various hand-dug wells and boreholes using plastic containers from 10 locations or neighbourhoods to generate 40 samples (10 from hand dug wells, appropriately $12-14 \mathrm{~m}$ deep and 10 from boreholes, appropriately $45 \mathrm{~m}$ deep) in each season. The sampling was carried out in the month of September,2011 for wet season and March 2012 for dry season. Samples for the trace metals analyses were preserved by the addition of concentrated nitric acid $\left(\mathrm{HNO}_{3}\right)$ to adjust the $\mathrm{pH}$ of the sample to below 2 to retard adsorption. The samples were kept in ice packs and transported to the laboratory where they were further preserved in a refrigerator before analysis $[15,16]$. 


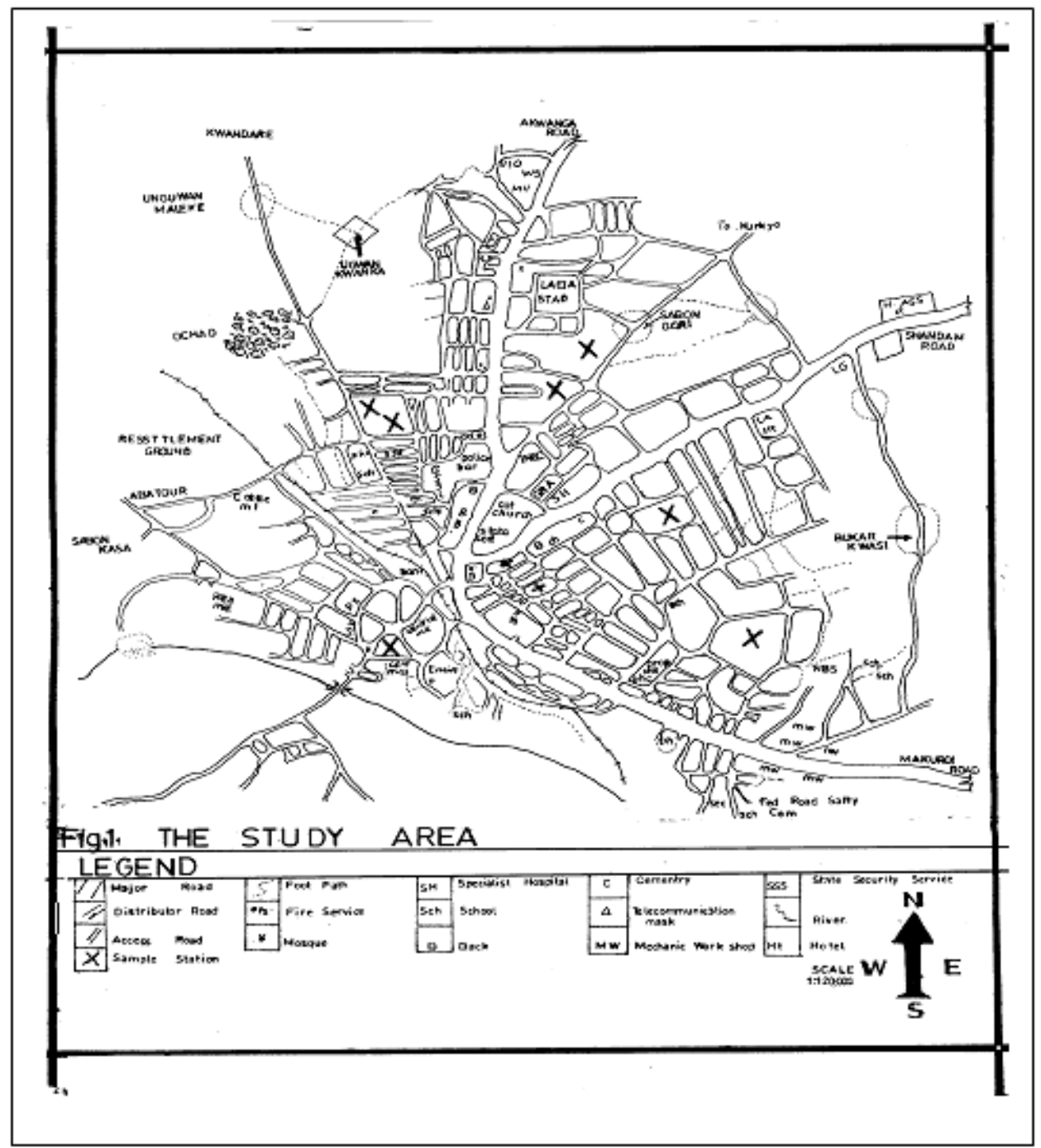

Fig.1 THE STUDY AREA

\section{4 pH Determination}

The $\mathrm{pH}$ of each of the sample was determined at each point of sample location after calibration of the $\mathrm{pH}$ meter using buffer solution [17].

\subsection{Extraction, preconcentration and analysis of trace metals}

The most valuable and commonly used procedure for extractive concentration of trace metals is that employing chelation with ammonium pyrrolidinedithiocarbamate (A.P.D.C.) by extraction into Methyl Isobutyl Ketone (M.I.B.K.). The extraction of charged species from an aqueous solution is not possible unless the charge can be neutralized by chelation. Since metals ions do not tend to dissolve appreciably in organic solvents, their charge must first of all be neutralized to make it "organic like". MIBK is widely used as a solvent in this technique because it has quite low solubility in water making it useful for liquid-liquid extraction.

Thus to $100 \mathrm{~mL}$ of each sample measured into $250 \mathrm{~mL}$ separating funnel, $4 \mathrm{~mL}$ of $5 \%$ APDC was added, followed by $25 \mathrm{~mL}$ Methyl Isobutyl Ketone (M.I.B.K). The separating funnel is stoppered and shaken manually for 5 minutes after which the organic phase separated to the bottom leaving the aqueous phase on top. The process was repeated so as to get enough extract. The organic trace metals extract of each sample was analysed using Atomic Absorption Spectrometry (AAS) against standards at the wavelengths of As $(248.3 \mathrm{~nm}$ ), Co $(240.7 \mathrm{~nm}), \mathrm{Cd}(309.3 \mathrm{~nm}), \mathrm{Cr}(248.3 \mathrm{~nm}), \mathrm{Pb}(217.0 \mathrm{~nm}), \mathrm{Al}(248.3 \mathrm{~nm}), \mathrm{Ni}(324.7 \mathrm{~nm}), \mathrm{Mn}(422.7 \mathrm{~nm})$. These standards were prepared in different concentrations; $1 \mathrm{ppm}, 3 \mathrm{ppm}, 5 \mathrm{ppm}$ or $10 \mathrm{ppm}$ from $1000 \mathrm{ppm}$ standards. Calibration curves were plotted from which the concentrations of the elements in each sample were extrapolated. Quality control was assured because all the determinations were in triplicate in addition to the use of standard reference materials, procedural blanks, relative standard deviations[18, 19,20]. 


\subsection{Statistical analysis of data}

The results obtained were analyzed statistically by using the mean value $(\mathrm{X})$, coefficient of variation (CV) and standard deviation (S) [21]. Furthermore, correlation tests were used to determine the significant relationship between the mean concentrations of trace metals obtained from $\mathrm{BH}$ and HDW using statistical package for social sciences SPSS version 16.

\subsection{Results}

\section{Results And Discussion}

Table 1 shows sample stations and their various locations within ten neighbourhoods.

Tables 2 and 3 presents results of $\mathrm{pH}$ determination for $\mathrm{BH}$ and HDW for wet and dry seasons.

Tables 4 and 5 show mean concentrations of trace metals campared between BH water samples on one hand and HDW water samples on the other hand for the two seasons. Similarly, Tables 6 and 7show mean concentrations of trace metals compared between BH and HDW on one hand in wet season and that between $\mathrm{BH}$ and HDW in dry season. Their corresponding variations (charts) are presented as Figures; 2A-2E, 3A-3E, $4 \mathrm{~A}-4 \mathrm{E}$ and $5 \mathrm{~A}-5 \mathrm{E}$. However, $\mathrm{Cd}$ and $\mathrm{Al}$ were not detected throughout the period.

\begin{tabular}{l|l}
\hline \multicolumn{2}{c}{ Table 1: Sample stations and their locations } \\
\hline \multicolumn{1}{c}{ Location } & \multicolumn{1}{c}{ Neighbourhood } \\
Lafia North & BukanSidi I \\
Ombi II & Millionaires Quarters \\
Lafia Central & National Supply \\
& TudunGwandara (Alhamis) \\
Lafia West & Shinge \\
Lafia South & Doma Road \\
& Emir's Palace (KofanFada) \\
Lafia East & Makurdi Road/Sabo Pegi \\
& Shendam Road \\
\hline
\end{tabular}

of pH of water samples from Borehole and hand-dug-well for wet season

\begin{tabular}{lllll}
\hline & \multicolumn{3}{c}{$\mathrm{pH}(\mathrm{HDW})$} \\
\hline Location & $\mathrm{pH}(\mathrm{BH})$ & \multicolumn{2}{c}{ Mean } & $\mathrm{CV} \%$ \\
Lafia North & $6.050 \pm 0.9192$ & 15.19 & $5.800 \pm 0.9899$ & 17.07 \\
Lafia Central & $5.300 \pm 0.1414$ & 2.668 & $5.100 \pm 0.7071$ & 13.86 \\
Lafia West & $5.450 \pm 0.2121$ & 3.892 & $4.850 \pm 0.3535$ & 7.289 \\
Lafia South & $5.300 \pm 0.4243$ & 8.006 & $4.850 \pm 2.000$ & 41.24 \\
Lafia East & $4.750 \pm 0.3536$ & 7.444 & $4.800 \pm 1.697$ & 35.35 \\
\hline
\end{tabular}

KEY: $\mathrm{BH}=$ Borehole

$\begin{array}{lll}\mathrm{HDW} & = & \text { Hand-dug-well } \\ \mathrm{CV} & = & \text { Coefficient of variation }\end{array}$

Table3: Mean values of $\mathrm{pH}$ of water samples from Borehole and hand dug well for dry season

\begin{tabular}{lllll} 
Location & Mean & CV \% & Mean & CV \% \\
Lafia North & $6.600 \pm 0.8485$ & 12.86 & $6.500 \pm 0.1414$ & 2.175 \\
Lafia Central & $5.750 \pm 0.2121$ & 3.689 & $5.450 \pm 1.060$ & 19.45 \\
Lafia West & $5.700 \pm 0.1414$ & 2.481 & $5.350 \pm 0.6364$ & 11.87 \\
Lafia South & $5.300 \pm 0.4243$ & 8.006 & $5.200 \pm 1.838$ & 35.35 \\
Lafia East & $5.650 \pm 0.2121$ & 3.750 & $5.40 \pm 2.404$ & 45.52 \\
\hline
\end{tabular}

KEY: $\mathrm{BH}=$ Borehole

HDW $=$ Hand-dug-well

$\mathrm{CV}=$ Coefficient of variation 
Table 4: Comparison of mean concentrations of some trace metals obtained from borehole (BH) water samples for wet and dry seasons

Concentration (mg/L)

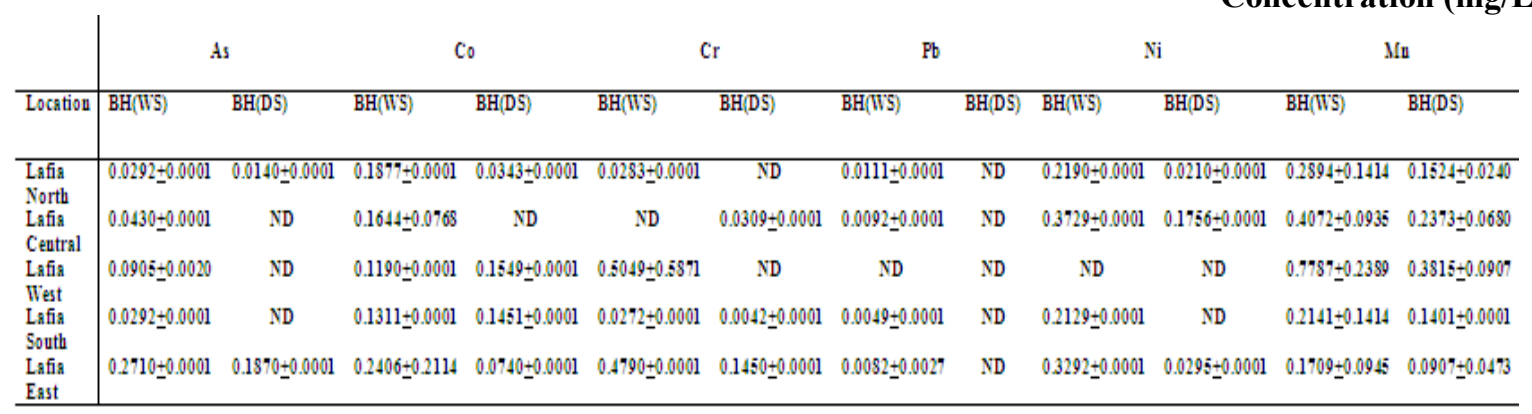

KEY: $\mathrm{BH}(\mathrm{WS}) \quad=\quad$ Borehole wet season

$\mathrm{BH}(\mathrm{DS})=\quad$ Borehole dry season

ND $\quad=\quad$ Not Detected

Table 5: Comparison of mean concentrations of some trace metals obtained from hand-dug well (HDW) water samples for wet and dry seasons

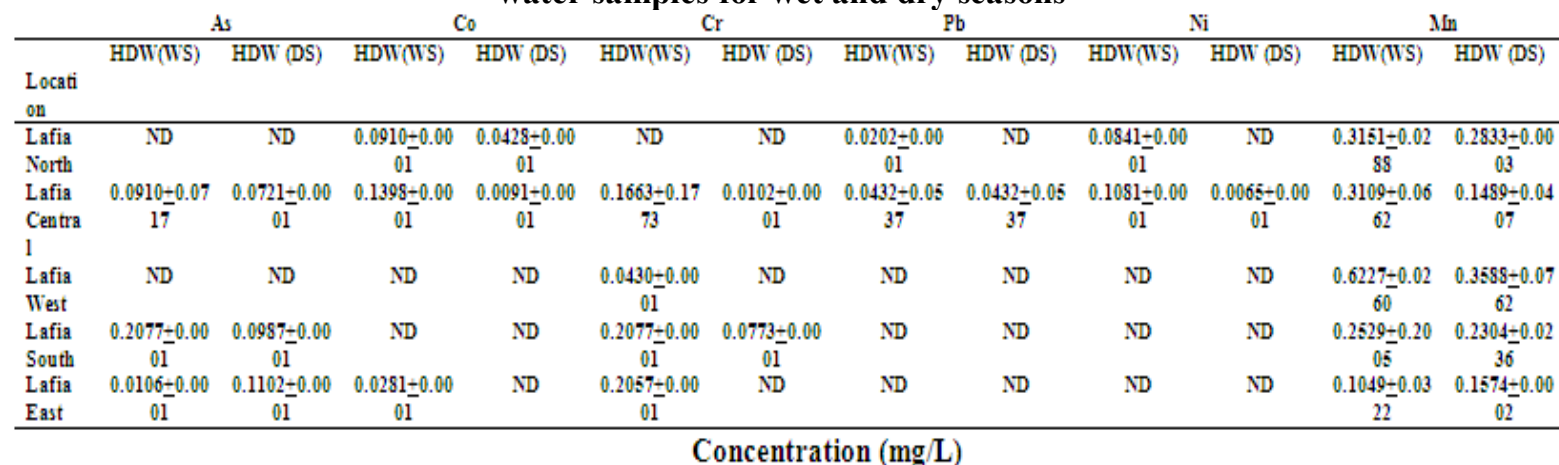

KEY: HDW(WS) = Hand-dug well wet season

HDW(DS) $\quad=\quad$ Hand - dug well dry season

ND $\quad=\quad$ Not Detected

Table 6: Comparison of mean concentrations of some trace metals obtained from $\mathrm{BH}$ and HDW water samples for wet season

Concentration $(\mathrm{mg} / \mathrm{L})$

\begin{tabular}{|c|c|c|c|c|c|c|c|c|c|c|c|c|}
\hline & \multicolumn{2}{|c|}{ As } & \multicolumn{2}{|c|}{$\mathrm{Co}$} & \multicolumn{2}{|c|}{$\mathrm{Cr}$} & \multicolumn{2}{|c|}{$\mathrm{Pb}$} & \multicolumn{2}{|c|}{$\mathrm{Ni}$} & \multicolumn{2}{|c|}{$\mathrm{Mn}$} \\
\hline $\begin{array}{l}\text { Locati } \\
\text { on }\end{array}$ & $\mathrm{BH}$ & HDW & $\mathrm{BH}$ & HDW & $\mathrm{BH}$ & HDW & $\mathrm{BH}$ & HDW & $\mathrm{BH}$ & HDW & $\mathrm{BH}$ & HDW \\
\hline $\begin{array}{l}\text { Lafia } \\
\text { North }\end{array}$ & $\begin{array}{c}0.02 \\
92 \pm 0 \\
.000 \\
1\end{array}$ & ND & $\begin{array}{c}0.1877 \\
+0.000 \\
1\end{array}$ & $\begin{array}{c}0.0910 \\
\pm 0.000 \\
1\end{array}$ & $\begin{array}{c}0.0283 \\
+0.000 \\
1\end{array}$ & ND & $\begin{array}{c}0.0111 \\
+0.000 \\
1\end{array}$ & $\begin{array}{c}0.0202 \\
+0.000 \\
1\end{array}$ & $\begin{array}{c}0.2190 \\
+0.000 \\
1\end{array}$ & $\begin{array}{c}0.0841 \\
+0.000 \\
1\end{array}$ & $\begin{array}{c}0.2894 \\
+0.141 \\
4\end{array}$ & $\begin{array}{c}0.3151 \\
+0.028 \\
8\end{array}$ \\
\hline $\begin{array}{l}\text { Lafia } \\
\text { Central }\end{array}$ & $\begin{array}{c}0.04 \\
30+0 \\
.000 \\
1\end{array}$ & $\begin{array}{c}0.0910 \\
+0.071 \\
7\end{array}$ & $\begin{array}{c}0.1644 \\
+0.076 \\
8\end{array}$ & $\begin{array}{c}0.1398 \\
+0.000 \\
1\end{array}$ & ND & $\begin{array}{c}0.1663 \\
+0.177 \\
3\end{array}$ & $\begin{array}{c}0.0092 \\
+0.000 \\
1\end{array}$ & $\begin{array}{c}0.0432 \\
+0.053 \\
7\end{array}$ & $\begin{array}{c}0.3729 \\
+0.000 \\
1\end{array}$ & $\begin{array}{c}0.1081 \\
+0.000 \\
1\end{array}$ & $\begin{array}{c}0.4072 \\
+0.093 \\
5\end{array}$ & $\begin{array}{c}0.3109 \\
+0.066 \\
2\end{array}$ \\
\hline $\begin{array}{l}\text { Lafia } \\
\text { West }\end{array}$ & $\begin{array}{c}0.09 \\
05+0 \\
.002 \\
0\end{array}$ & ND & $\begin{array}{c}0.1190 \\
+0.000 \\
1\end{array}$ & ND & $\begin{array}{c}0.5049 \\
+0.587 \\
1\end{array}$ & $\begin{array}{c}0.0430 \\
\pm 0.000 \\
1\end{array}$ & ND & ND & ND & ND & $\begin{array}{c}0.7787 \\
\pm 0.238 \\
9\end{array}$ & $\begin{array}{c}0.6227 \\
+0.026 \\
0\end{array}$ \\
\hline $\begin{array}{l}\text { Lafia } \\
\text { South }\end{array}$ & $\begin{array}{c}0.02 \\
92+0 \\
.000 \\
1\end{array}$ & $\begin{array}{c}0.2077 \\
+0.000 \\
1\end{array}$ & $\begin{array}{c}0.1311 \\
+0.000 \\
1\end{array}$ & ND & $\begin{array}{c}0.0272 \\
+0.000 \\
1\end{array}$ & $\begin{array}{c}0.2077 \\
+0.000 \\
1\end{array}$ & $\begin{array}{c}0.0049 \\
+0.000 \\
1\end{array}$ & ND & $\begin{array}{c}0.2129 \\
+0.000 \\
1\end{array}$ & ND & $\begin{array}{c}0.2141 \\
+0.141 \\
4\end{array}$ & $\begin{array}{c}0.2529 \\
+0.200 \\
5\end{array}$ \\
\hline $\begin{array}{l}\text { Lafia } \\
\text { East }\end{array}$ & $\begin{array}{c}0.27 \\
10 \pm 0 \\
.000 \\
1\end{array}$ & $\begin{array}{c}0.0106 \\
+0.000 \\
1\end{array}$ & $\begin{array}{c}0.2406 \\
+0.211 \\
4\end{array}$ & $\begin{array}{c}0.0281 \\
+0.000 \\
1\end{array}$ & $\begin{array}{c}0.4790 \\
+0.000 \\
1\end{array}$ & $\begin{array}{c}0.2057 \\
+0.000 \\
1\end{array}$ & $\begin{array}{c}0.0082 \\
+0.002 \\
7\end{array}$ & ND & $\begin{array}{c}0.3292 \\
+0.000 \\
1\end{array}$ & ND & $\begin{array}{c}0.1709 \\
+0.094 \\
5\end{array}$ & $\begin{array}{c}0.1049 \\
+0.032 \\
2\end{array}$ \\
\hline
\end{tabular}

KEY: $\mathrm{BH}=$ Borehole, $\mathrm{HDW}=\quad$ Hand dug well, ND $=$ Not Detected 
Table 7: Comparison of mean concentrations of some trace metals obtained from BH and HDW water samples for dry season

\begin{tabular}{|c|c|c|c|c|c|c|c|c|c|c|c|c|}
\hline & & & & & & & & & & Col & entratio & $1(\mathrm{mg} / \mathrm{L})$ \\
\hline & $A$ & & & & & & & $\mathrm{~Pb}$ & & ii & & \\
\hline $\begin{array}{l}\text { Locatio } \\
\text { n }\end{array}$ & BH & HDW & BH & HDW & $\mathrm{BH}$ & HDW & $\begin{array}{l}\text { B } \\
\mathrm{H}\end{array}$ & $\mathrm{HD} W$ & $\mathrm{BH}$ & HDW & BH & HDW \\
\hline Lafia & $0.0140 \pm 0.00$ & $\mathrm{ND}$ & $0.0343 \pm 0.00$ & $0.0428 \pm 0.00$ & ND & $\mathrm{ND}$ & $\mathrm{N}$ & $\mathrm{ND}$ & $0.0210 \pm 0.00$ & $\mathrm{ND}$ & $0.1524 \pm 0.02$ & $0.2833 \pm 0.00$ \\
\hline North & $0 \overline{1}$ & & $0 \overline{1}$ & 01 & & & D & & 01 & & $40^{-}$ & 03 \\
\hline $\begin{array}{l}\text { Lafia } \\
\text { Central }\end{array}$ & ND & $\begin{array}{c}0.0721 \pm 0.00 \\
01\end{array}$ & ND & $\begin{array}{c}0.0091 \pm 0.00 \\
01\end{array}$ & $\begin{array}{c}0.0309+0.00 \\
01\end{array}$ & $\begin{array}{c}0.0102 \pm 0.00 \\
01\end{array}$ & $\begin{array}{l}\mathrm{N} \\
\mathrm{D}\end{array}$ & $\underset{37}{0.0432 \pm 0.05}$ & $\begin{array}{c}0.1756+0.00 \\
01\end{array}$ & $\begin{array}{c}0.0065 \pm 0.00 \\
01\end{array}$ & $\begin{array}{c}0.2373+0.06 \\
80\end{array}$ & $\begin{array}{c}0.1489+0.04 \\
07\end{array}$ \\
\hline $\begin{array}{l}\text { Lafia } \\
\text { West }\end{array}$ & ND & $\mathrm{ND}$ & $0.1549 \pm 0.00$ & $N D$ & ND & $\mathrm{ND}$ & N & $\mathrm{ND}$ & ND & ND & $0.3815 \div 0.09$ & $0.3588 \div 0.07$ \\
\hline $\begin{array}{l}\text { Lafia } \\
\text { South }\end{array}$ & ND & $\begin{array}{c}0.0987 \pm 0.00 \\
01\end{array}$ & $\begin{array}{c}0.1451+0.00 \\
0 \overline{1}\end{array}$ & $\mathrm{ND}$ & $\begin{array}{c}0.0042 \pm 0.00 \\
0 \overline{1}\end{array}$ & $\begin{array}{c}0.0773 \pm 0.00 \\
0 \overline{1}\end{array}$ & $\begin{array}{l}\text { N } \\
\text { D }\end{array}$ & $\mathrm{ND}$ & $\mathrm{ND}$ & $\mathrm{ND}$ & $\begin{array}{c}0.1401 \pm 0.00 \\
01\end{array}$ & $\frac{0.2304 \div 0.02}{36}$ \\
\hline $\begin{array}{l}\text { Lafia } \\
\text { East }\end{array}$ & $\begin{array}{c}0.1870 \pm 0.00 \\
01\end{array}$ & $\begin{array}{c}0.1102+0.00 \\
01\end{array}$ & $\begin{array}{c}0.0740 \pm 0.00 \\
01\end{array}$ & $\mathrm{ND}$ & $\begin{array}{c}0.1450 \pm 0.00 \\
01\end{array}$ & $\mathrm{ND}$ & $\begin{array}{l}\mathrm{N} \\
\mathrm{D}\end{array}$ & ND & $\begin{array}{c}0.0295+0.00 \\
01\end{array}$ & ND & $\begin{array}{c}0.0907 \pm 0.04 \\
73\end{array}$ & $\begin{array}{c}0.1574+0.00 \\
02\end{array}$ \\
\hline
\end{tabular}

KEY: $\mathrm{BH}=$ Borehole, $\mathrm{HDW}=$ Hand dug well, $\mathrm{ND}=$ Not Detected

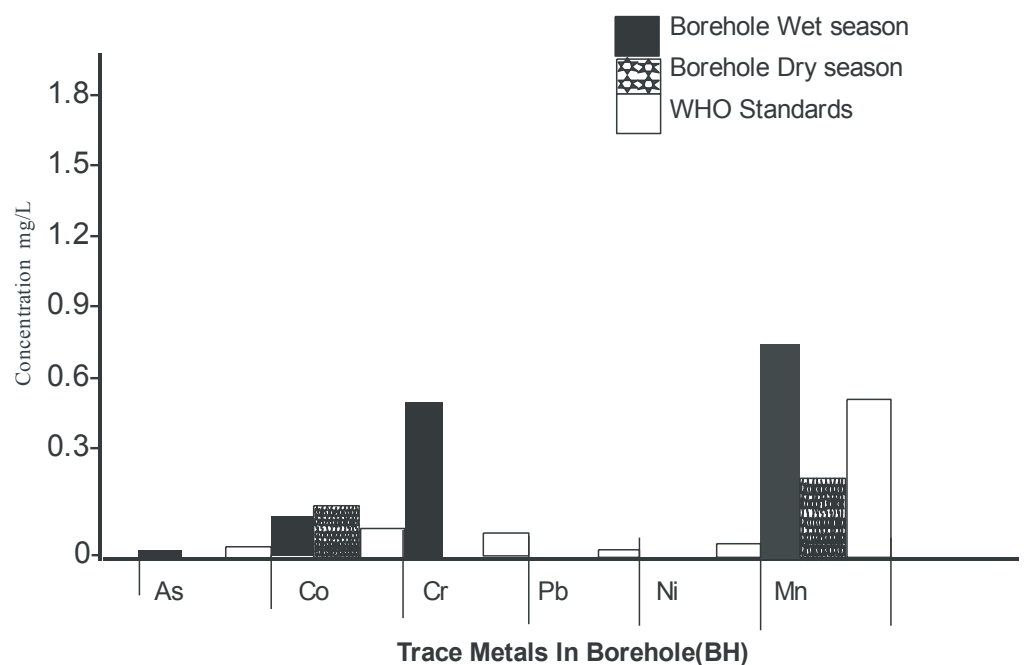

Fig. 2C: Variation of mean concentration of trace metals in borehole for both wet and dry seasons in Lafia West

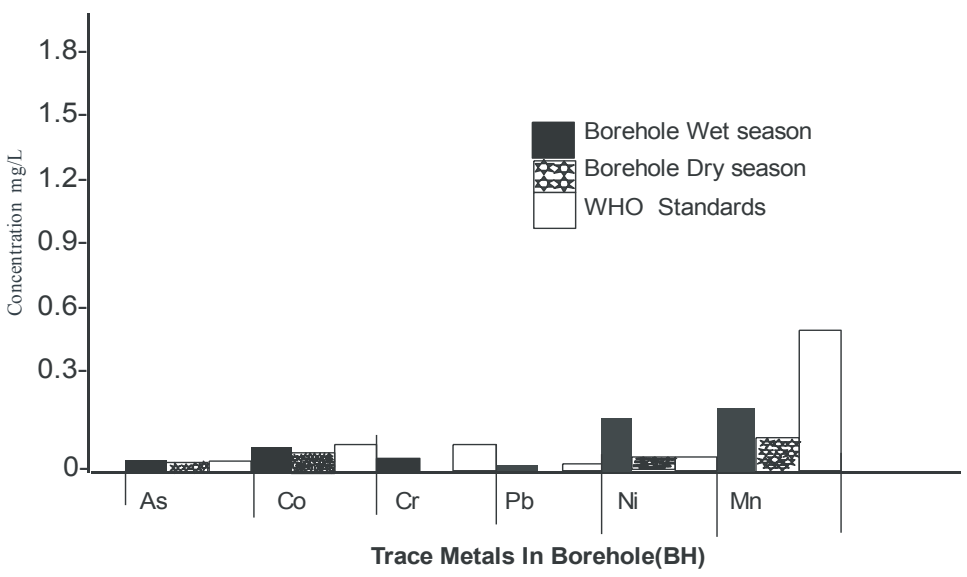

Figure 2A: Variation of mean concentration of trace metals in borehole for both wet and dry seasons in LafiaNorth 


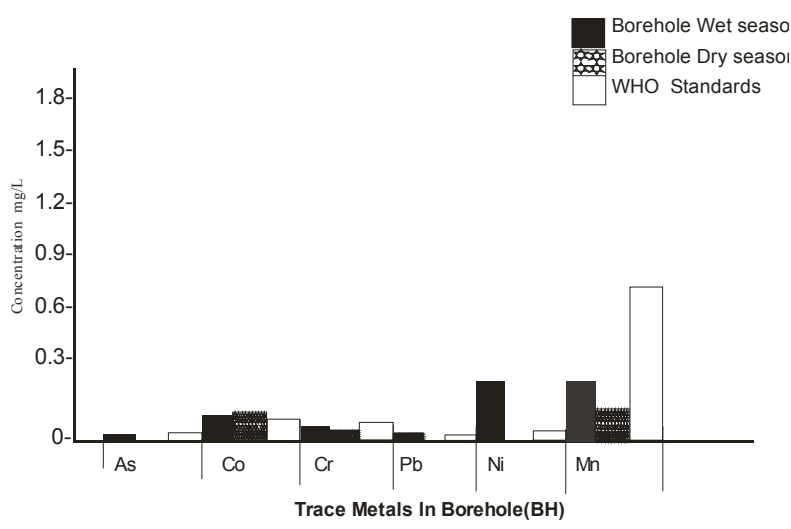

Fig. 2D: Variation of mean concentration of trace metals in borehole for both wet and dry seasons in Lafia South

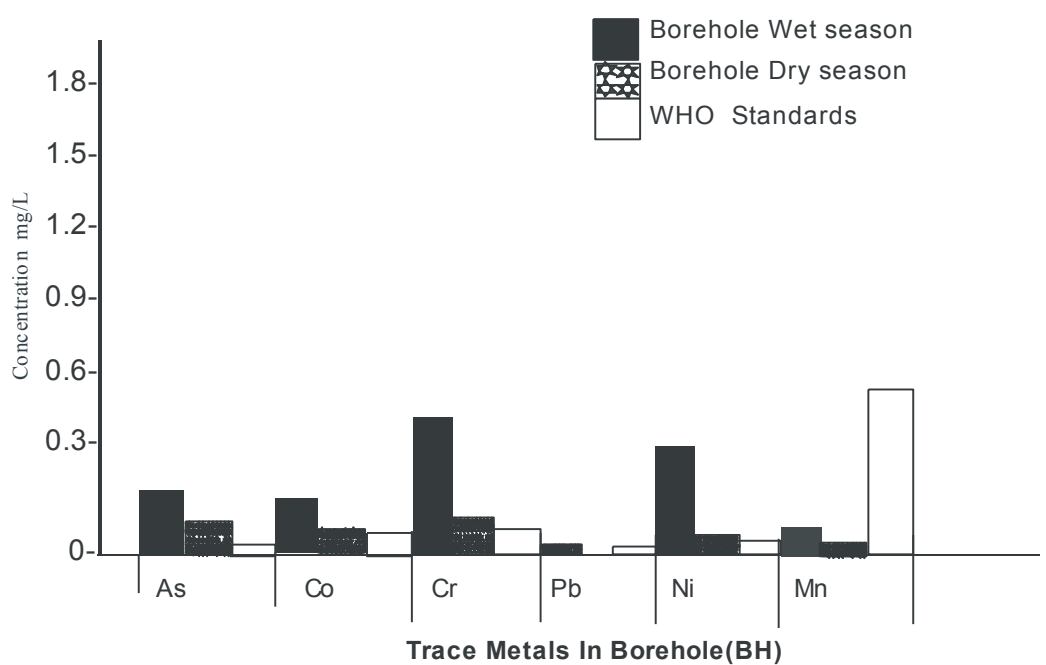

Fig. 2E: Variation of mean concentration ofrace metals in borehole for both wet and dry seasons in Lafia East

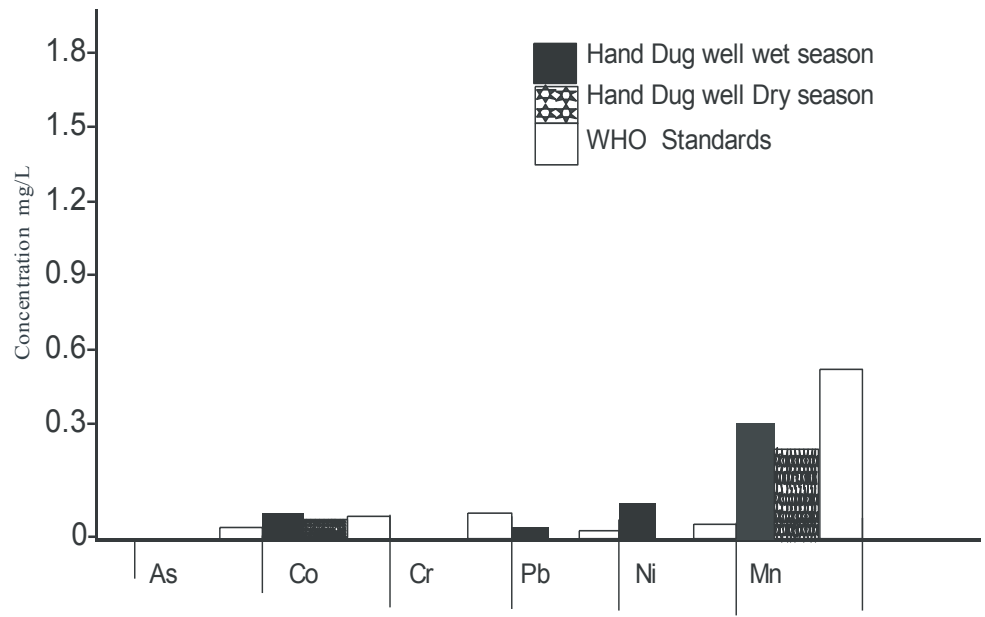

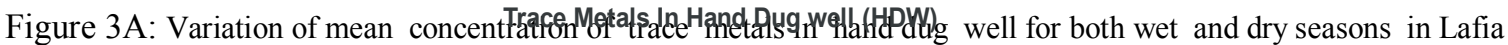
North 


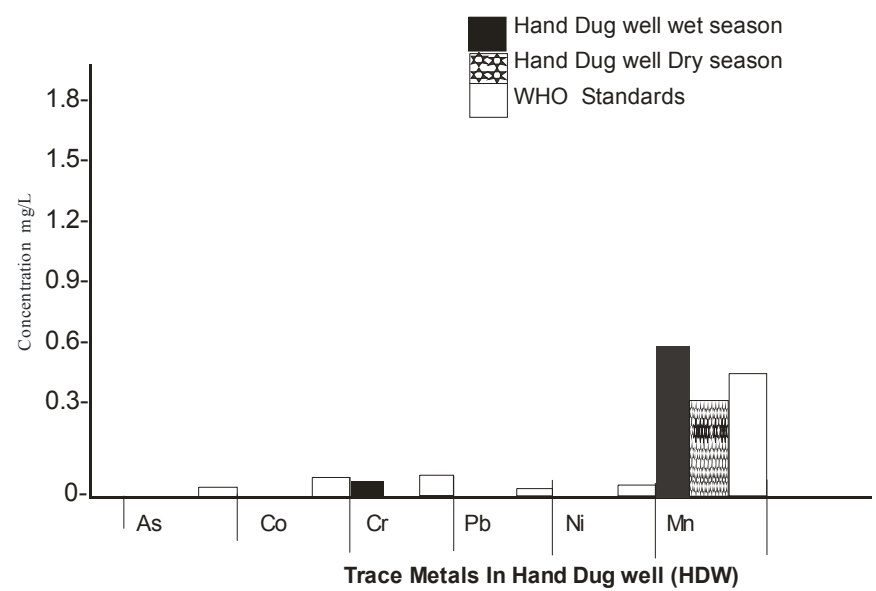

Fig. 3C: Variation of mean concentration of trace metals in hand dug well for both wet and dry seasons in Lafia West

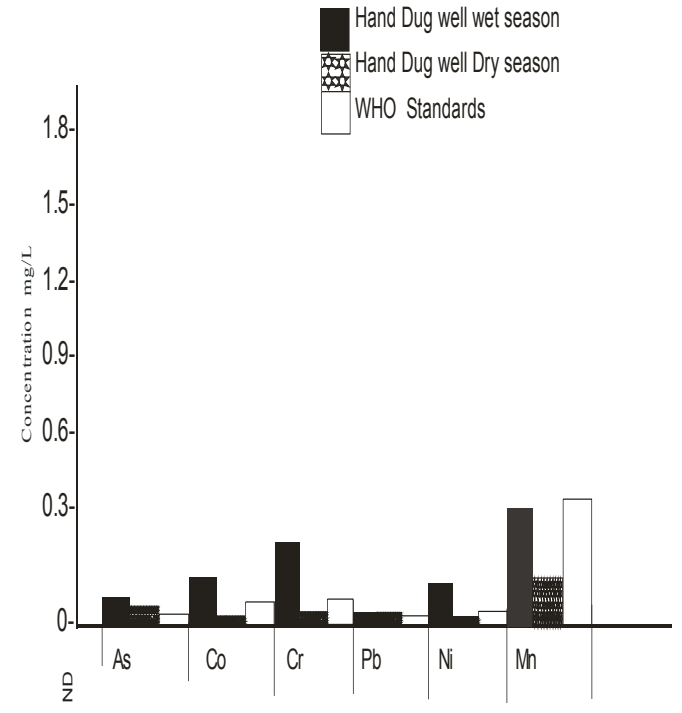

Trace Metals In Hand Dug well (HDW) Fig. 3B: Variation of mean concentration ofrace metals in hand dug well for both wet and dry seasons in Laficentral

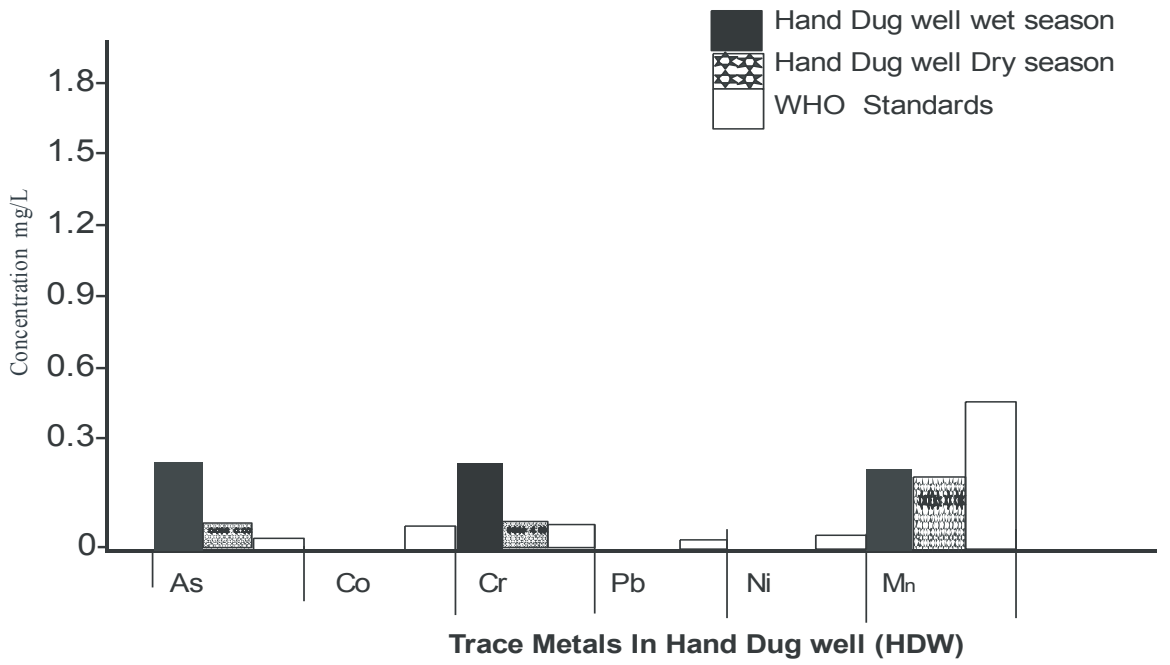




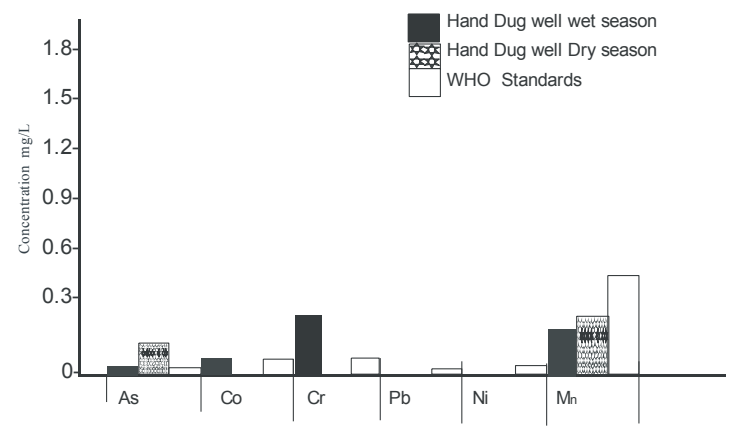

Fig. 3E: Variation of mean conc.of trace metals in hand dug well for both wet and dry seasons in Lafia East

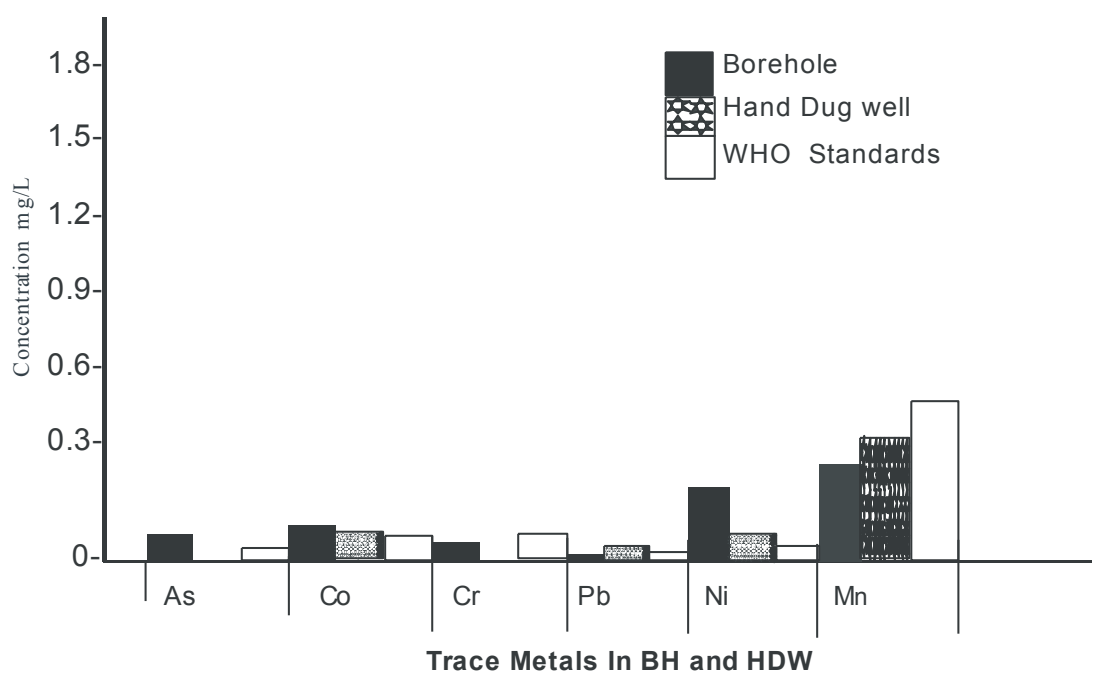

Fig. 4A: Variation of mean concentration of trace metalsin BH and HDW for wet season in Lafia North 


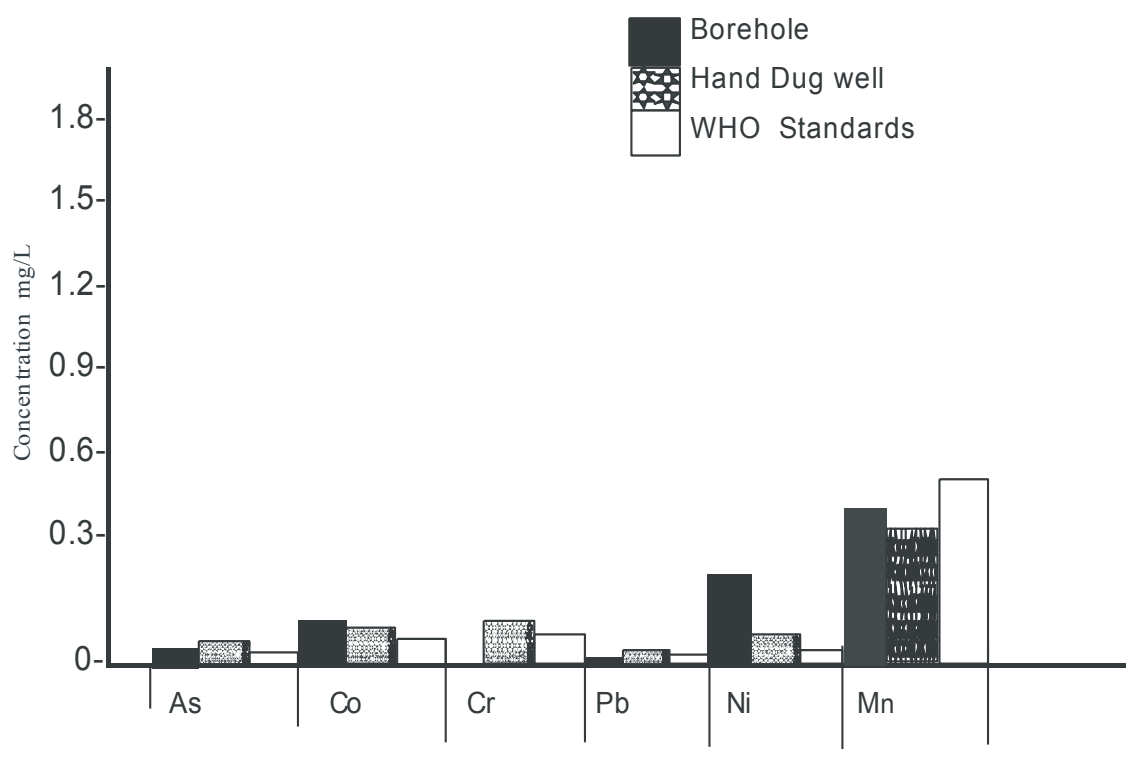

Trace Metals In BH and HDW

Fig. 4B: Variation of mean concentration oftrace metals in BH and HDW for wet season in Lafia Central

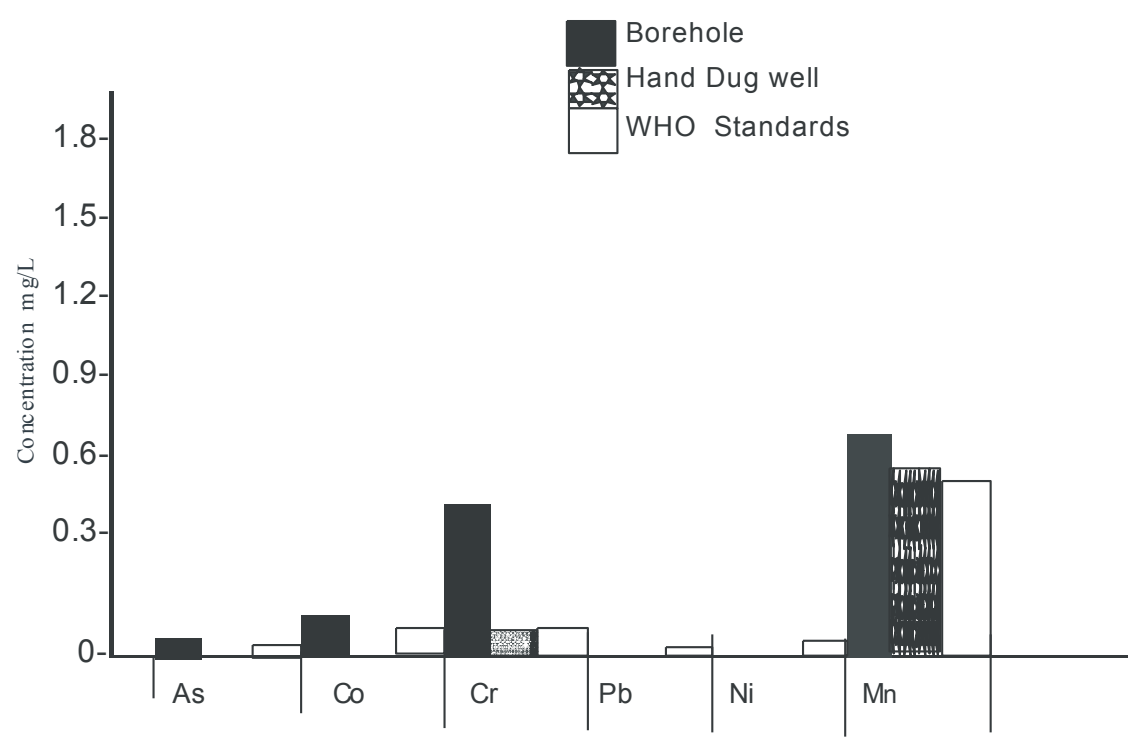

Trace Metals In BH and HDW

Fig. 4C: Variation of mean concentration of trace metals in BH and HDW for wet season in Lafia West 


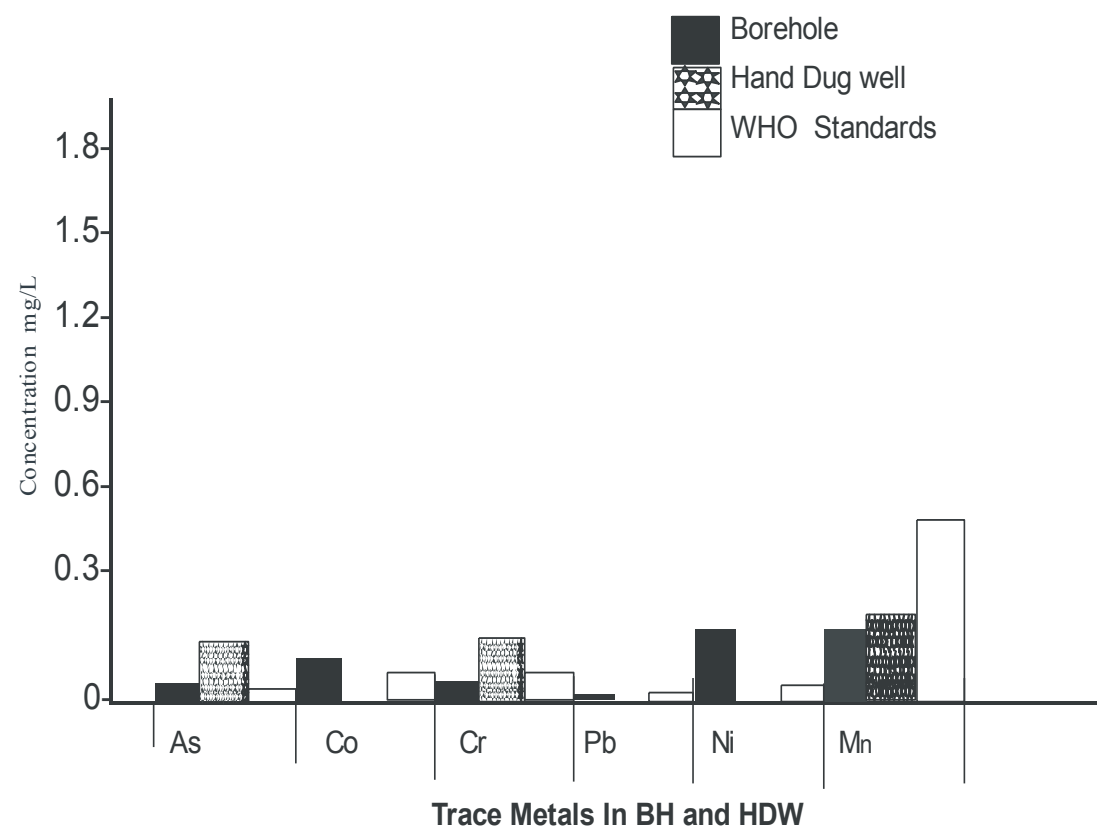

Fig. 4D: Variation of mean concentration of trace metals in BH and HDW for wet season in Lafia South

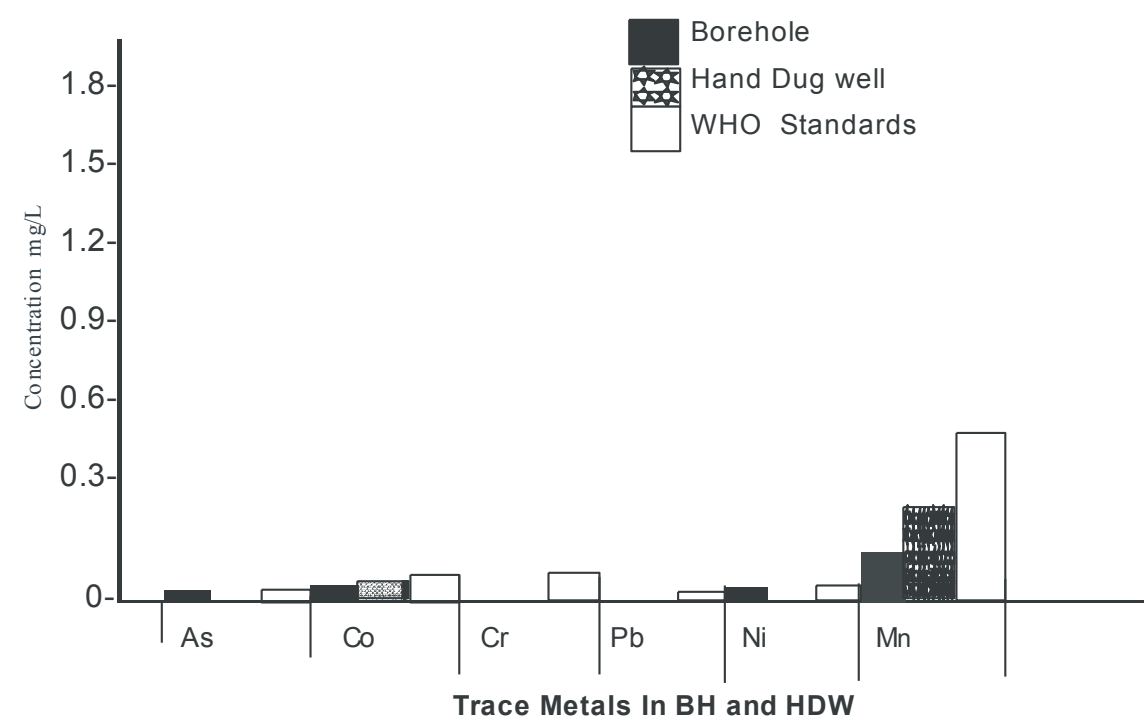

Fig. 5A: Variation of mean concentration of trace metals in BH and HDW for wet season in Lafia North 


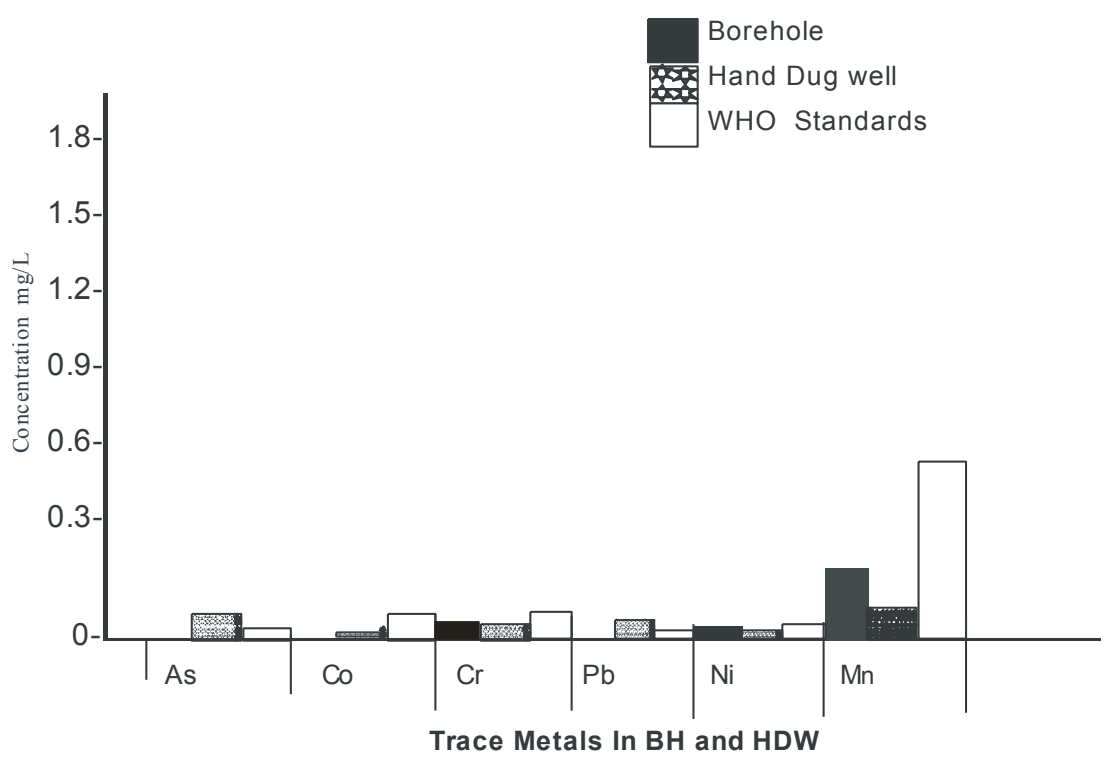

Fig. 5B: Variation of mean concentration of trace metals in BH and HDW for dry season in Lafia Central

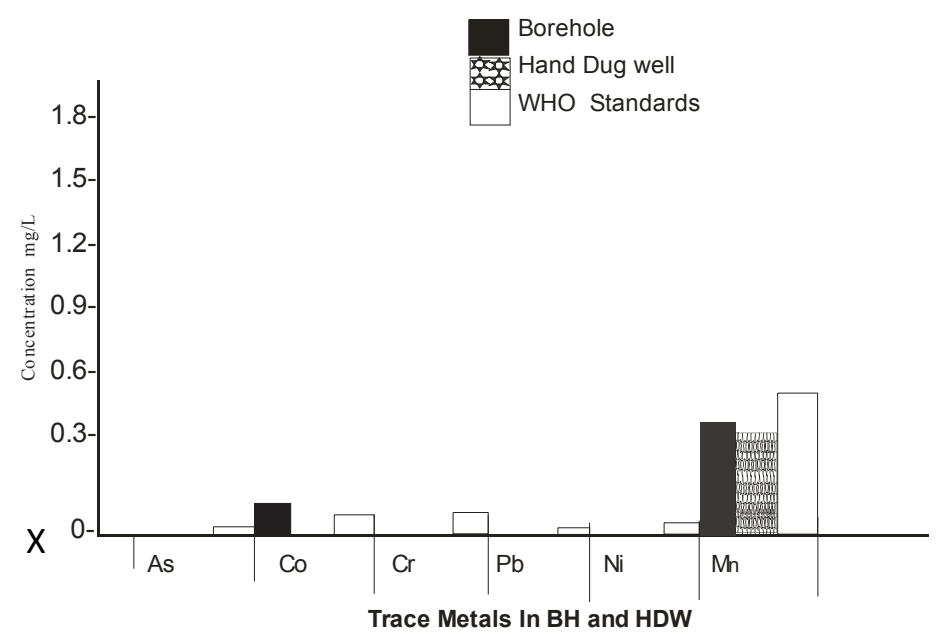

Fig. 5C: Variation of mean concentration of trace metals in $\mathrm{BH}$ and $\mathrm{HDW}$ for dry season in Lafia West

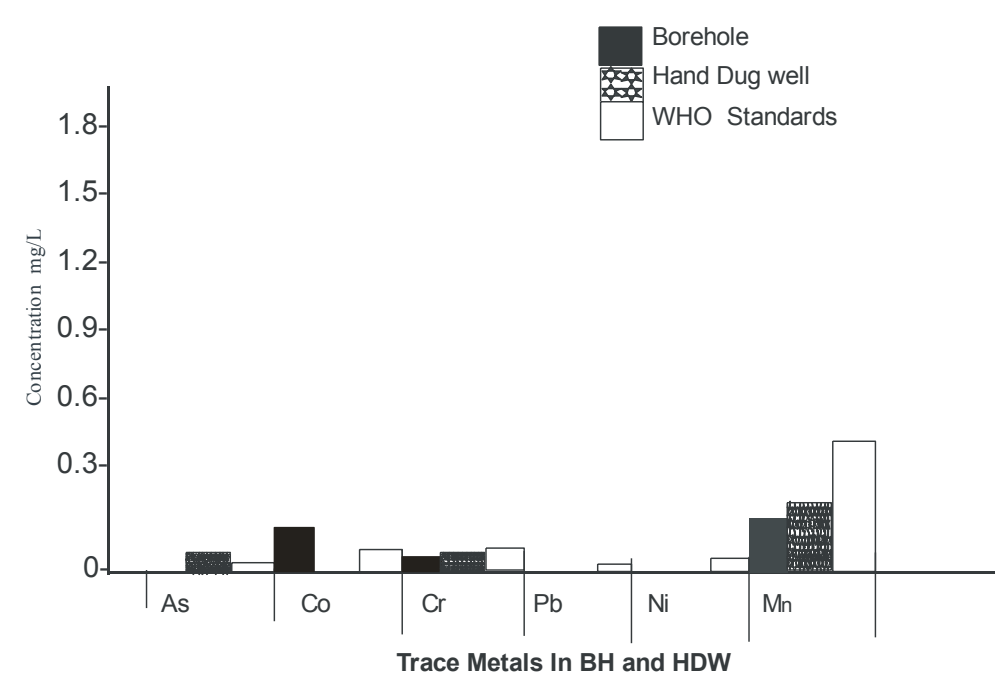

Fig. 5D: Variation of mean concentration of trace metals in BH and HDW for dry season in Lafia South 


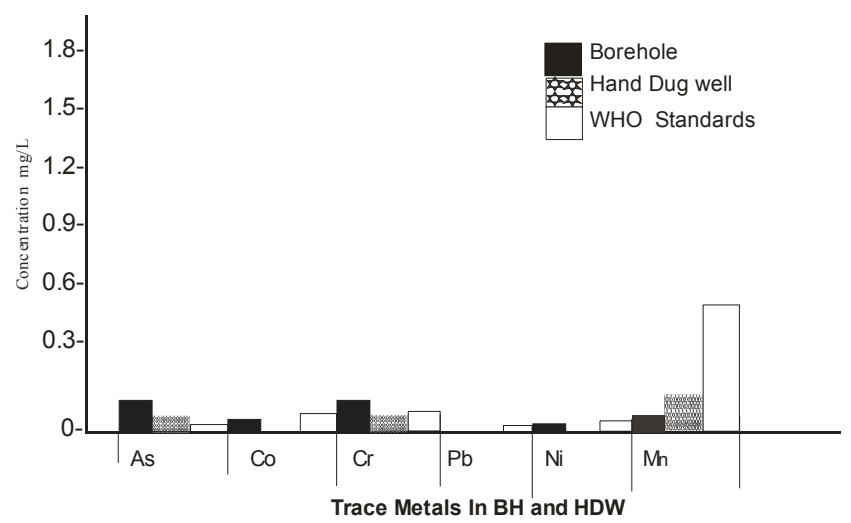

Fig. 5E: Variation of mean concentration of trace metals in $\mathrm{BH}$ and HDW for dry season in Lafia East

\subsection{Discussion}

The results of analyses of some trace metals studied are shown in Tables 4,5,6 and 7. The trace metal with the highest mean concentration during WS was $\mathrm{Mn}(0.7787 \pm 0.2389 \mathrm{mg} / \mathrm{L})$ for $\mathrm{BH}$ in Lafia West while the least concentrated metal for the same season is $\mathrm{Pb}(0.0049+0.0001 \mathrm{mg} / \mathrm{L})$ for $\mathrm{BH}$ water samples in Lafia South. Similarly for HDW water samples in wet season, the highest mean concentration was Mn $(0.6227 \pm 0.0260$ $\mathrm{mg} / \mathrm{L})$ in Lafia West while the least was As $(0.0106 \pm 0.0001 \mathrm{mg} / \mathrm{L})$ in Lafia East. In the case of DS, the highest concentrated metal was $\mathrm{Mn}(0.3815 \pm 0.0907 \mathrm{mg} / \mathrm{L})$ for $\mathrm{BH}$ in Lafia West while the least concentrated metal was $\operatorname{Cr}(0.0042 \pm 0.0001 \mathrm{mg} / \mathrm{L})$ for $\mathrm{HDW}$ in Lafia South. Similarly for HDW in dry season, the highest was $\operatorname{Mn}(0.3580 \pm 0.0762 \mathrm{mg} / \mathrm{L})$ in Lafia West while the least was $\mathrm{Ni}(0.0065 \pm 0.0001 \mathrm{mg} / \mathrm{L})$ in Lafia Central.

The following metals were not within the detection limit in both seasons namely $\mathrm{Cd}, \mathrm{Al}$. When compared, the level of trace metals for $\mathrm{BH}$ and $\mathrm{HDW}$ for WS, with the highest variation was found in $\mathrm{Cr}(116.2 \%, \mathrm{BH})$ in Lafia West and $\mathrm{Pb}(124.3 \% \mathrm{HDW})$ in Lafia Central while the least were $\mathrm{Ni}(0.0268 \% \mathrm{BH})$ in Lafia Central; As(0.0481\% HDW) and $\operatorname{Cr}(0.0481 \%$ HDW) all in Lafia South. Similarly, the highest variation during the dry season (DS) occurred for $\mathrm{Mn}(52.15 \% \mathrm{BH})$ in Lafia East and $\mathrm{Pb}(124.3 \%$, HDW) in Lafia Central while the least were $\mathrm{As}(0.0535 \% \mathrm{BH}$ and $\mathrm{As}(0.0907 \% \mathrm{HDW})$ all in Lafia East.

In Tables 2 and 3Lafia North had the highest mean $\mathrm{pH} 6.050 \pm 0.9192$ (slightly acidic) for borehole (BH) during the wet season (WS), while the least $\mathrm{pH}$ of $4.750 \pm 0.353 \overline{6}$ (moderately acidic) occurred at Lafia East for Borehole (BH). Similarly during, the Dry Season (DS), Lafia North had the highest pH of $6.600 \pm 0$ .8485 (slightly acidic) for $\mathrm{BH}$ while the least $\mathrm{pH}$ of $5.200 \pm 1.838$ was recorded for HDW in Lafia South.

These mean $\mathrm{pH}$ values, except for $\mathrm{BH}$ in Lafia North are not in agreement with the standard guidelines by WHO, NAFDAC ( $\mathrm{pH}$ 6.5-8.5) indicating that the $\mathrm{BH}$ and HDW water samples are not suitable for drinking and other purposes. These values are consistent with the works of Mcbride (1994) which warned that levels of certain soluble metals particularly $\mathrm{Al}^{3+}, \mathrm{Mn}^{2+}$ at such $\mathrm{pH}$ 5.0-5.5 would be high enough to be biologically toxic [22].

The reason may be due to the level of minerals in the area and run-offs of various wastes. Soil $\mathrm{pH}$ plays a major function in the sorption of trace metals as it directly controls the solubility and hydrolysis of metal hydroxides, carbonates and phosphates. It also influences ion-pair formation, solubility of organic matter as well as surface charge of $\mathrm{Fe}, \mathrm{Mn}$ and Al-oxides, organic matter and clay edges [23].

Table 4 compares results generated for BH between the two seasons and variations presented (Fig. 2A$2 \mathrm{E})$. The mean concentrations of all the metals investigated decreased from WS to DS. Similarly in the case of HDW, presented in Table 5, the mean concentration of the five metals investigated decreased generally from WS to DS (Fig. 3A-3E). However the variation is significant in HDW between the two seasons for all the parameters investigated [24].

Tables 6, 7 compares mean concentrations of metals for $\mathrm{BH}$ and HDW during wet season on one hand and dry season on the other. The variations are presented graphically in (Fig. 4A-4E) (Table 6), and Fig. 5A-5E (Table 7). In all the locations during the wet season, there is marked difference in mean concentrations between $\mathrm{BH}$ and HDW, with $\mathrm{BH}$ recording higher values than HDW in all the locations except in Lafia South where the 
trend is $50 \%$ in favour of HDW and $50 \%$ in favour of $\mathrm{BH}$. However, during the dry season, $50 \%$ of the samples (BH, HDW) had no trace metals detected. For the remaining $50 \%$ of the samples, trace metals in both $\mathrm{BH}$, HDW were detected in equal proportion and low concentrations and significantly low difference between $\mathrm{BH}$ and HDW.

In summary, the mean concentrations of trace metals in the BH and HDW water samples were higher during the wet season than dry season. This is most likely due to leaching from already weathered materials which is enhanced during rainy season. Another reason could be due to geological formation (solid minerals) status of Lafia town and increased run-offs of wastes into source waters [25].

\section{Conclusion}

The study presented data on the concentration of trace metals ( $\mathrm{As}, \mathrm{Co}, \mathrm{Cr}, \mathrm{Pb}, \mathrm{Ni}, \mathrm{Mn}$ ) in ground water sources; Boreholes and Hand dug wells collected from various locations within and around Lafia metropolis. The results revealed that there were indications of trace metals in the following proportion As $40 \%$, Co $40 \%, \mathrm{Cr}$ $37.5 \%, \mathrm{~Pb} 25 \%$, Ni $25 \%, \mathrm{Mn} 97.5 \%$ of the total water samples and their contents were found to be higher in some cases than the recommended guideline values by WHO, NAFDAC, NSDWQ (borehole monitoring unit of Federal Ministry of Water Resources). These levels of trace metals could be due to contribution by the geology of Lafia metropolis, which hosts minerals like Columbite, Tantalite, Cassiterite, run-offs of wastes from anthropogenic activities. This means that water sources from BH and HDW are polluted by these metals and will pose danger to consumers. It is well known that minerals are necessary for life performing important function in the metabolism of living organism. On the other hand, when taken in excess both toxicity and necessity vary from element to element and from species to species. Over millions of years, men and other living creatures have become tolerant to these small concentrations of heavy metals and it is more than likely that some forms of life may now be dependent on these poisonous metals as trace elements. Therefore this information onthe levels ofintake of trace metals through water is important in assessing risk to human health arising from increasing environmental pollution.

\section{References}

[1] World Health Organization (WHO), (2006). Guideline for Drinking Water Quality. (Recommendation WHO, Geneva), 1-3, 569571.

[2] Wells, R.G. (1977). Water quality standard and criteria.Water Pollution and Control 77-25-30.

[3]. Freeze, R. A. and Cherry A.J. (1979).Ground Water Eaglewood Cliffs, N.S Prentice Hal. Inc.416-417.

[4]. Ahmed, S.H. (2002). Water Quality.General Module of National Water Supply Training Network, National Water Rehabilitation Project.58-72. [5]. Welsey, J.J. (1986). How much metals in our waters . Environ SciTechnol. Vol. 8 (2).[6]. WHO (1997). Standard Parameters for potable water Vol.2 Geneva 15.

[7]. Basset, J. Denney, R.C. Jeffery, G.N. and Mendham, J. (1978). A Textbook of Quantitative Inorganic analysis $4^{\text {th }}$ ed.ELBS, \& Longman, London. 811 .

[8]. Adepeju- Bello, A.A.Ojomolade, O.O.Ayoola, G.A. and Coker, H.A.B.(2009). Quantitative analysis of some toxic metals in domestic water obtained from Lagos metropolis. TheNigeria.J.Pharm 42(1): 56-60

[9] Waziri, M; Ogubuaji, V.O and Dimari, G.A. (2009). Heavy metal concentration in surface and ground water sample from Gashua and Nguru Areas of Yobe State Nigeria. Integrated Journal of Science and Engineering 8(11) 58-63.[12] Gafia Master Plan (1999). A publication of savannah LandevKonsult Ltd for NasarawaState Government 3 (3). Thunder bold Printers R.C. No. 866186.

[13] Akwa, V. L. Binbol, N. L. Samaila, K. I. and Markus, N. D. (2007). Geographical Perspective on Nasarawa State. A publication of GeographyDepartmentNasarawaStateUniversity, Keffi, Nigeria .

[14] Okegye, J. I. (2000). Heavy metals pollution from mining practices; a case study of UDEGE MBEKI- A paper presentation at NasarawaState Polytechnic $3^{\text {rd }}$ ASUP Conference(Unpublished).

[15] United States Environmental Protection Agency, (2007) .Solutions to Analytical Chemistry, problems with clean water Act Methods.

[16] Christian, G. D. (1986). Analytical Chemistry $4^{\text {th }}$ Edition. John Wiley \& Sons Inc. :424-430

[17] Gray, N. F. (2008) Drinking Water Quality $2^{\text {nd }}$ ed. CambridgeUniversity Press.

[18] Extraction intomethylisobutyl Ketone with Ammonium Pyrolidinedithiocarbamate formed in strongly acidic media.mhthml:file//c/users/Hp/Documents- Accessed $10^{\text {th }}$ August,2011

[19] APDC-MIBK extraction system for the determination of trace elements in saline waters by AAS. mhthml:file/ /c/users/Hp/Documents- Accessed $10^{\text {th }}$ August,2011

[20] APHA,AWWA and WEF, (2005). Standard Methods for the Examination of Water and Waste Water. Edited by Anold, E.G. Joseph, J.C. and David, J. 15th edDonelley RR and Sons Company, U.S.A : 547.

[21] James, C. S. (1995). Analytical Chemistry of Foods, AspenPublishers. Foster, H. D. (1994). "Ground water Resources of British Columbia, Ministry of Environment, Lands and Parks, Canada: 61-63.

[22] Aremu, M. O. Ozonyia, G. N. and Ikokoh, P. P. (2011): Physicochemical properties of well, Borehole and stream waters in Kubwa, Bwari Area Council, FCT, Nigeria EJEAF Chem10 (6): 2296-2304.

[23] Wuana R. A. Okieimen, F. E. and Iorhemen, D. A. T. (2009). Chemical speciation of heavy metals in spiked soil in the vicinity of the Benue industrial layout and assessment uptake by maize (Zea Mays L) Journal of chemical society of Nigeria, Vol. 34 (1): 5-14.

[24]. Obunwo, C. C. Chindah, A. C. and Braide, S. A. (2012). Assessment of the physico-chemical characteristics of Minichida stream, Port Harcourt, Nigeria. Journal of Chemical Society of Nigeria; Vol. 37, (1): 132-136.

[25]. Osibanjo O. Ajayi, S. O. and Mombeshira C. (1981). Pollution studies on Nigeria waters toxic metal status on surface waters in Ibadan city. Environment International; 5: 45-54. 